Article

\title{
Extraction, Structural Characterisation, and Immunomodulatory Properties of Edible Amanita hemibapha subspecies javanica (Corner and Bas) Mucilage Polysaccharide as a Potential of Functional Food
}

\author{
Utoomporn Surayot ${ }^{1}{ }^{(}$, Sutee Wangtueai ${ }^{1}{ }^{(0)}$, SangGuan You ${ }^{2,3}$, Subramanian Palanisamy ${ }^{2,3}$, Warawut Krusong ${ }^{4}$, \\ Charles S. Brennan ${ }^{5}{ }^{(0}$, Francisco J. Barba ${ }^{6} \odot$, Yuthana Phimolsiripol ${ }^{7,8} \mathbb{C}^{-}$and Phisit Seesuriyachan ${ }^{7,8,9, *}$
}

check for updates

Citation: Surayot, U.; Wangtueai, S.; You, S.; Palanisamy, S.; Krusong, W.; Brennan, C.S.; Barba, F.J.;

Phimolsiripol, Y.; Seesuriyachan, P. Extraction, Structural

Characterisation, and

Immunomodulatory Properties of Edible Amanita hemibapha subspecies javanica (Corner and Bas) Mucilage Polysaccharide as a Potential of Functional Food. J. Fungi 2021, 7, 683. https://doi.org/10.3390/jof7090683

Academic Editor: Laurent Dufossé

Received: 4 August 2021

Accepted: 20 August 2021

Published: 24 August 2021

Publisher's Note: MDPI stays neutral with regard to jurisdictional claims in published maps and institutional affiliations.

Copyright: (c) 2021 by the authors. Licensee MDPI, Basel, Switzerland. This article is an open access article distributed under the terms and conditions of the Creative Commons Attribution (CC BY) license (https:// creativecommons.org/licenses/by/ $4.0 /)$.
1 College of Maritime Studies and Management, Chiang Mai University, Samut Sakhon 74000, Thailand; utoomporn.su@cmu.ac.th (U.S.); sutee.w@cmu.ac.th (S.W.)

2 Department of Marine Food Science and Technology, Gangneung-Wonju National University, Gangwon 210-702, Korea; umyousg@gwnu.ac.kr (S.Y.); spalanisamy33@gwnu.ac.kr (S.P.)

3 East Coast Life Sciences Institute, Gangneung-Wonju National University, Gangwon 210-720, Korea

4 Division of Fermentation Technology, Faculty of Food Industry, King Mongkut's Institute of Technology Ladkrabang, Bangkok 10520, Thailand; warawut.kr@kmitl.ac.th

5 School of Science, STEM College, RMIT University, Melbourne 3000, Australia; charles.brennan@rmit.edu.au

6 Department of Preventive Medicine and Public Health, Food Science, Toxicology and Forensic Medicine, Faculty of Pharmacy, Universitat de València, Avda. Vicent Andrés Estellés s/n, 46100 Burjassot, Spain; francisco.barba@uv.es

7 Faculty of Agro-Industry, Chiang Mai University, Chiang Mai 50100, Thailand; yuthana.p@cmu.ac.th 8 Cluster of Agro Bio-Circular-Green Industry, Chiang Mai University, Chiang Mai 50100, Thailand

9 Advanced Manufacturing and Management Technology Research Center (AM2Tech), Department of Industrial Engineering, Faculty of Engineering, Chiang Mai University, Chiang Mai 50200, Thailand

* Correspondence: phisit.s@cmu.ac.th; Tel.: +66-53-948-223

\begin{abstract}
This research aimed to extract mucilage polysaccharides (MP) from Amanita hemibapha subspecies javanica (Corner and Bas), and further fractionate them using anion-exchange chromatography, yielding two fractions (MPF1 and MPF2). The crude extract, and fractions mainly consisted of carbohydrates (83.5-93.2\%) with minor amounts of proteins (5.40-7.20\%), and sulphates (1.40-9.30\%). Determination of the monosaccharide composition revealed that glucose was the major unit, followed by galactose, mannose, rhamnose, and arabinose. The average molecular weight (MW) of the crude extract and fractions was in the range 104.0-479.4 $\times 10^{3} \mathrm{~g} / \mathrm{mol}$. Interestingly, the crude extract, and fractions did not cause any toxic effect in RAW264.7 cells. However, they stimulated the RAW264.7 cells to release nitric oxide and cytokines through the activation of nuclear factor-kappa B (NF-kB), and mitogen-activated protein kinase (MAPK) pathways via cell surface TLR4. Structural analysis of the most immunestimulating extract fraction, MPF2, revealed that the main backbone consisted of $\alpha$ $\mathrm{D}-(1 \rightarrow 6)$-glucopyranoside. These results suggest that the MPs derived from A. hemibapha subspecies javanica (Corner and Bas) are potent in enhancing immunity; hence, they can be used as a functional ingredient in food products.
\end{abstract}

Keywords: mucilage polysaccharide; mushroom; Amanita hemibapha subspecies javanica (Corner and Bas); immunomodulatory property; fractionation; functional food

\section{Introduction}

Mushrooms are special groups of fungi, and there may be a particular growth of mushroom species associated with the seasons. Mushrooms are considered a healthy food, being a great source of minerals, dietary fibre, and vitamins [1], which can be applied in pasta [2], meat [3], and bread for enhancing the nutritional properties [4]. There has been recent interest in mushrooms not only to satisfy hunger or provide nutrition, but 
also as a source of biologically active compounds of medicinal value. Moreover, their uses include complementary medicine or dietary supplements for anticancer, antiviral, immunostimulatory, hepatoprotective, and hypocholesterolaemic agents, which has urged a global market for natural foods consumed as dietary supplements [5].

Amanita hemibapha subspecies javanica (Corner and Bas) is an edible mushroom, and one of the most popular wild mushrooms in Thailand. This species belongs to the genus Amanita, which grows in the north, and north-east regions of Thailand where it is traditionally gathered, and consumed as a food. The mushrooms have their own special taste, and a distinctive flavour. Usually, the fungus, and its host, such as insects, are mostly consumed in various countries including Japan, China, and Korea because it contains high nutritional benefits such as anti-ageing, immunomodulatory, and anticancer properties as well as encourages improvement of renal function [6-8]. The existence of chemical constituents such as polysaccharides, proteins, mannitol, fatty acids, and trace elements may be responsible for many biological functions of the fungus [9]. A. hemibapha subspecies javanica secretes polysaccharide-rich mucilage when cooked or in contact with water. The mucilage is a thick, slimy polysaccharide, and is used to thicken soups, and stews. It is a common component of plants such as okra (Abelmoschus esculentus) [10], aloe (Aloe vera) [11], linseed (Linum usitatissimum) [12], and rice bran (Oryza sativa L.) [13,14]. A previous study showed the great potential of the bioactive components of A. hemibapha subspecies javanica to scavenge the hydroxyl radical, being, for instance, an excellent source of antioxidant compounds [15].

Nowadays, polysaccharides from fungi have attracted great attention in biochemical, and nutritional studies due to their potential in the development of new functional foods, and nutraceuticals. Many studies have reported that polysaccharides from mushrooms have a variety of types of bioactivities such as immunomodulatory, antioxidant, anticancer, antibacterial, and anti-inflammatory bioactivities, as shown in Table 1. This table shows extraction methods, and the bioactivity of polysaccharides from mushrooms [16-24]. The immunostimulatory activity is due to the great potential of polysaccharides such as lentinan, schizophyllan, and $\beta$-glucan to modulate the immune system [25]. In the immune system, macrophages play a role in innate immunity, serving as a first line to protect against pathogens, and tumours. Moreover, macrophages also connect the innate, and adaptive immunity. It has been reported that the polysaccharide $\beta$-glucan from the edible mushroom Entoloma lividoalbum acts as an immune-enhancing agent via macrophage, splenocyte, and thymocyte cells, and also exhibits antioxidant activity [26]. Treatment with VGPI-a polysaccharide isolated from Volvariella—showed an immunostimulatory effect on RAW264.7 cells by enhancing the mRNA expression of NO, and cytokines, and also showed upregulation via the mitogen-activated protein kinase (MAPK) signalling pathway [27]. Another in vitro study on the immunomodulatory activity of polysaccharides from Cantharellus cibarius Fr. showed that they have an immunomodulatory effect by inducing phagocytosis, and higher levels of NO, and cytokines [16]. The immunomodulatory activity is influenced by the chemical composition, molecular weight, structure, branching, configuration, and conformation of polysaccharides [28,29].

Table 1. Extraction methods, and bioactivities of polysaccharide from mushrooms.

\begin{tabular}{|c|c|c|c|}
\hline Polysaccharide & Bioactivity & Extraction Method & References \\
\hline Cantharellus cibarius & Immunomodulatory activity & \multirow{3}{*}{$\begin{array}{l}\text { Boiling water extraction } \\
\text { Hot water extraction }\left(80^{\circ} \mathrm{C}\right) \text {, and } \\
\text { ultrasound-assisted extraction } \\
\text { Hot water extraction } \\
\left(95-100^{\circ} \mathrm{C}\right)\end{array}$} & [16] \\
\hline Flammulina velutipes & $\begin{array}{c}\text { Immunomodulatory, and antioxidant } \\
\text { activity }\end{array}$ & & [17] \\
\hline Cordyceps sinensis & Anticancer, and antioxidant activity & & {$[18,21]$} \\
\hline Lepista nuda & $\begin{array}{c}\text { Antioxidant, antitumor, and antiviral } \\
\text { activities }\end{array}$ & Water extraction $\left(75-95^{\circ} \mathrm{C}\right)$ & [19] \\
\hline Lentinus edodes & Reno-protective activity & Water extraction $\left(85^{\circ} \mathrm{C}\right)$ & [20] \\
\hline Collybia radicata & Immunomodulatory activity & Water extraction $\left(84^{\circ} \mathrm{C}\right)$ & [22] \\
\hline Ganoderma lucidum & Anti-inflammatory & Boiling water extraction & [23] \\
\hline $\begin{array}{c}\text { Auricularia } \\
\text { auricula-judae (Bull.) }\end{array}$ & Skin wound-healing & Water extraction $\left(97^{\circ} \mathrm{C}\right)$ & {$[24]$} \\
\hline
\end{tabular}


However, there are no studies evaluating the molecular structures, and bioactivity of mucilage polysaccharides from A. hemibapha subspecies javanica in the available literature. Therefore, in the present work, the mucilage polysaccharides from the A. hemibapha subspecies javanica fruiting body were extracted using hot water extraction, and fractionated by anion-exchange chromatography. Structural analysis was carried out using gas chromatography-mass spectrometry (GC-MS) to determine the monosaccharide composition, and glycosidic linkage. Meanwhile, high-performance size exclusion chromatography was used for measurement of molecular weight, and both 1D, and 2D nuclear magnetic resonance (NMR) analyses were used for assessing the structure. Furthermore, RAW264.7 cell activation was tested by various in vitro assays to confirm the immunostimulatory properties of the polysaccharide, which can be further applied as a functional food ingredient in food, and beverage products as well as in dietary supplements.

\section{Materials and Methods}

\subsection{Raw Materials, and Reagents}

The fruiting bodies of the wild mushroom A. hemibapha subspecies javanica were purchased from the local market in Chiang Mai, Thailand, in 2018. They were carefully washed with tap water, and dried using a hot air oven at $60^{\circ} \mathrm{C}$ for $3 \mathrm{~h}$. The dried sample was finely milled with a grinder into powder, and stored at $-20{ }^{\circ} \mathrm{C}$. RPMI- 1640 cell culture medium, fetal bovine serum (FBS), streptomycin, and penicillin were purchased from Gibco Life Technologies (Grand Island, NY, USA). Griess reagent was purchased from Sigma-Aldrich (NSW, Australia). The EZ-Cytox cell viability assay kit (WST-1) was purchased from Daeil Lab Service Co., Ltd., Korea. The anti-complement receptor 3 antibody (anti-CR3), and anti-toll-like receptor 4 antibody (anti-TLR4) were obtained from Abcam (Cambridge, MA, USA). The phospho-NF- $\mathrm{kB}$ antibody, phospho-p38 antibody (MAPK), phospho-ERK (MAPK) antibody, and phospho-JNK antibody were purchased from Cell Signaling Technology (Danvers, MA, USA). All other chemicals, and reagents used in this study were of high analytical grade.

\subsection{Mucilage Polysaccharide Extraction}

Five hundred grams of dried mushroom powder was dissolved in $1000 \mathrm{~mL}$ of distilled water. The mixture was then heated at $60{ }^{\circ} \mathrm{C}$ under constant stirring for $1 \mathrm{~h}$. The concentrated solution was cooled to room temperature, and filtrated through a muslin cloth. Approximately $20 \mathrm{~mL}$ of acetone was added to the concentrated solution. The mucilage was filtered through a muslin cloth, and cooled again. Trichloroacetic acid $(80 \%)$ was added to the supernatant, which was then stored at $4{ }^{\circ} \mathrm{C}$ for $30 \mathrm{~min}$, and centrifuged (4000 rpm for $10 \mathrm{~min}$ ). The supernatant was mixed with three volumes of ethanol (EtOH, $99 \%$ ), and stored at $4{ }^{\circ} \mathrm{C}$ overnight to precipitate the crude mucilage polysaccharides (MPs). The obtained MPs were thoroughly washed with $\mathrm{EtOH}$, and dried at room temperature. The yield of the isolated polysaccharides was calculated in relation to the depigmented powder obtained after the $99 \% \mathrm{EtOH}$ treatment.

\subsection{Fractionation of $M P s$}

Briefly, MPs $(150 \mathrm{mg})$ were dissolved in distilled water $(10 \mathrm{~mL})$, and the solution was injected into a DEAE-Sepharose fast flow column (17-070-01; GE Healthcare BioScience AB, Uppsala, Sweden) equilibrated with distilled water. The polysaccharides were eluted with distilled water to obtain a neutral polysaccharide, and subsequently eluted with a stepwise $\mathrm{NaCl}$ gradient $(0.5-2.0 \mathrm{M})$ at a flow rate of $1.5 \mathrm{~mL} / \mathrm{min}$; the polyanionic polysaccharides were then collected. The obtained fractions were identified by phenolsulphuric acid assay, and all fractions were extensively dialysed (3K MWCO) against distilled water for 3 days, and then lyophilised.

Two fractions were obtained, referred to as mucilage polysaccharide fraction 1 (MPF1), and mucilage polysaccharide fraction 2 (MPF2). 


\subsection{Chemical Composition of Polysaccharides}

The phenol-sulphuric acid method was employed to determine the sugar content, using D-glucose as a reference [30]. The protein content was evaluated by the Lowry method using a Bio-Rad DC Protein assay kit [30]. The sulphate content was calculated by hydrolysing the polysaccharide with $0.5 \mathrm{M} \mathrm{HCl}$, and then following the $\mathrm{BaCl}_{2}$ gelatin method using $\mathrm{K}_{2} \mathrm{SO}_{4}$ as a standard [31]. The uronic acid content was determined by a sulphamate/m-hydroxydiphenyl assay using glucuronic acid as a standard [32]. The average molecular weight $(\mathrm{MW})$, and radius of the gyration $(R g)$ of the polysaccharides were determined using a high-performance size exclusion chromatography column (TSK G5000PW column) coupled to UV, multi-angle laser light scattering, and a refractive index detection system (HPSEC-UV-MALLS-RI) according to a previously described method [33].

\subsection{Analysis of Monosaccharide Composition, and Absolute Configuration}

The monosaccharide composition was determined by GC following reduction, and acetylation. Briefly, samples ( $3 \mathrm{mg}$ ) were hydrolysed with $4 \mathrm{~mL}$ of $4 \mathrm{M}$ trifluoracetic acid (TFA) at $100{ }^{\circ} \mathrm{C}$ for $6 \mathrm{~h}$. Excess TFA was removed with methanol, and the mixture was reduced through the addition of sodium borodeuteride $\left(\mathrm{NaBD}_{4}\right)$ solution. Acetylation was conducted with acetic anhydride to give alditol acetates, which were determined by GC-MS (6890N/MSD 5973, Agilent Technologies, Santa Clara, CA, USA) using an HP-5MS capillary column. Monosaccharide standards (arabinose, xylose, rhamnose, mannose, glucose, and galactose) were used as references. The absolute configuration of the monosaccharide was analysed by GLC with acetylated (R)-2-methylheptyl glycosides as described previously [34].

\subsection{Methylation Analysis}

Methylation analysis was carried out to determine the types of linkage between residues according to the method of Cao et al. (2014) with slight modifications. The polysaccharide (2-3 mg) was dissolved in $0.5 \mathrm{~mL}$ dimethyl sulphoxide (DMSO). Methyl iodide $\left(\mathrm{CH}_{3} \mathrm{I}\right)$ was added for methylation. The methylated polysaccharides were hydrolysed with $4 \mathrm{M}$ TFA at $100{ }^{\circ} \mathrm{C}$ for $6 \mathrm{~h}$. The hydrolysates were then reduced in distilled water with $\mathrm{NaBD}_{4}$, and acetylated with acetic anhydride. The acetylated derivatives were extracted with methylene chloride. The partially methylated alditol acetates were analysed by GC-MS using methods previously published by Cao et al. (2014) [31].

\subsection{NMR Spectroscopy}

The NMR spectra were obtained from the sample $(10 \mathrm{mg})$ after desulphation that was dissolved in $\mathrm{D}_{2} \mathrm{O}(0.5 \mathrm{~mL})$. The ${ }^{1} \mathrm{H}$, and ${ }^{13} \mathrm{C}$ NMR spectra of the sample were recorded on a JEOL ECA-600 spectrometer (JEOL, Akishima, Japan) at $70{ }^{\circ} \mathrm{C}$ at a base frequency of $150 \mathrm{MHz}$ for ${ }^{13} \mathrm{C}$, and $600 \mathrm{MHz}$ for ${ }^{1} \mathrm{H}$. Two-dimensional COSY, and HMQC experiments were processed using the pulse programs.

\subsection{RAW264.7 Macrophage Proliferation, and Nitric Oxide (NO) Production Assay}

In the macrophage cell proliferation assay, RAW264.7 cells were determined according to the WST-1 method. The RAW264.7 cells $(100 \mu \mathrm{L})$ were plated into a 96-well plate at $1 \times 10^{6}$ cells/well in RPMI-1640 medium containing 10\% FBS. The samples (MP, MFP1, and MPF2) were added at different concentrations (50,100, and $200 \mu \mathrm{g} / \mathrm{mL}$ ), and the medium was used as the control. The 96 -well plate was incubated at $37^{\circ} \mathrm{C}$ with $5 \% \mathrm{CO}_{2}$ for $24 \mathrm{~h}$. After incubation, 10\% WST-1 solution was added to each well, and the plate was further incubated for $1 \mathrm{~h}$. The absorbance was determined using a microplate reader, and measured at $450 \mathrm{~nm}$ (EL-800; BioTek Instruments, Winooski, VT, USA).

The NO production assay was conducted by the Griess method [35]. In brief, RAW264.7 cells $\left(1 \times 10^{6}\right.$ cells/well) were seeded in a 96-well plate, and treated with polysaccharides for $24 \mathrm{~h}$. Treatment with lipopolysaccharide (LPS; $1 \mu \mathrm{g} / \mathrm{mL}$ ) (Sigma-Aldrich, St. Louis, $\mathrm{MO}$, USA) served as a positive control. After incubation, an equal volume of the Griess 
reagent was mixed with the supernatants. The absorbance was read at $540 \mathrm{~nm}$ using a microplate reader. NO production was calculated using a standard curve.

\subsection{Gene Expression by RT-PCR}

The RAW264.7 cells were seeded in a 24-well plate at a density of $1 \times 10^{6}$ cells/well, and incubated with samples or the LPS stimulant. After $24 \mathrm{~h}$, the cells were extracted using the TRIzol reagent (Invitrogen, Carlsbad, CA, USA). The concentration of RNA was measured with a spectrophotometer before constructing cDNA with an oligo-(dT)20 primer, and Superscript III RT (Invitrogen). The resulting cDNA was amplified by PCR using GoTaq Flexi DNA Polymerase (Promega, Madison, WI, USA). Reverse transcriptase amplification was conducted with initial denaturation, denaturation, annealing, and extension, followed by a final extension step. The PCR product gels were viewed under UV transillumination. The nucleotide sequences of the primers used were as previously reported (Table S1) [32].

\subsection{Western Blot Analysis}

Western blotting was performed according to standard procedure. The RAW264.7 cells were seeded at $1 \times 10^{6}$ cells/well in a 6-well plate, and then treated with LPS or samples for $6 \mathrm{~h}$. The RAW264.7 cells were lysed in RIPA buffer (Tech, and Innovation, Chuncheon, Gangwon, South Korea) containing Inhibitor Cocktail (HaltTM protease, and phosphatase). Cell lysates were separated through 10\% SDS-PAGE, and transferred onto PVDF membranes. The membranes were subsequently blocked in 5\% non-fat skimmed milk (prepared in Tris-buffer saline containing Tween-20, TBST) at room temperature for 1 $h$, and incubated with primary antibodies including $\beta$-actin (1:1000), anti-phospho-NF- $\mathrm{B}$ (1:1000), anti-phospho-ERK (1:1000), anti-phospho-p38, and anti-phospho-JNK (1:1000) at $4{ }^{\circ} \mathrm{C}$ overnight. The membranes were washed with TBST, and incubated with HRPconjugated anti-rabbit antibody for $1 \mathrm{~h}$ at room temperature. Protein was detected using the Pierce ${ }^{\circledR}$ ECL Plus Western Blotting Substrate (Thermo Scientific, Waltham, MA, USA) in accordance with the manufacturer's instructions (Table S2). The bands were obtained using Image Lab software under a ChemiDocTM imaging system.

\subsection{Investigation of Cell Membrane Binding Receptors}

The RAW264.7 cells were adjusted to a concentration of $1 \times 10^{5}$ cells/well in a 96-well plate. The cells were pre-treated with antibodies (anti-TLR4, and anti-CR3, $30 \mu \mathrm{g} / \mathrm{mL}$ ) for $2 \mathrm{~h}$, and treated with polysaccharides $(200 \mu \mathrm{g} / \mathrm{mL})$ [36]. The level of NO from the RAW264.7 cells was investigated using the methods described above.

\subsection{Statistical Analysis}

All experiments were repeated at least three times. The data values are expressed as the mean $\pm S D(n \geq 3)$. Statistical analysis was performed using SAS software (SAS Institute, Cary, NC, USA). The differences between groups were analysed using one-way analysis of variance (ANOVA). Significance was defined as a $p$-value of $<0.05$. Duncan's multiple range test was used for means comparison.

\section{Results and Discussion}

\subsection{Yield, and Chemical Composition}

As can be seen in Table 2, the total yield of the crude MPs from the mushroom A. hemibapha subspecies javanica was $4.90 \%$, which was lower than the yield value of polysaccharide from the mushroom Auricularia auricula-judae (8.90\%) [24]. The discrepancy might be due to the differences in temperature, and time of extraction used [37]. The crude polysaccharides obtained mostly consisted of carbohydrates $(87.8 \%)$, and were significantly higher than other components, with considerable amounts of protein $(6.80 \%)$, and sulphate $(5.40 \%)$. Uronic acids were not found in the MPs. The monosaccharide composition analysis showed that glucose $(85.5 \%)$ was the main component of the crude polysaccharide, along with small amounts of galactose $(6.80 \%)$, mannose $(3.30 \%)$, xylose $(1.10 \%)$, arabinose 
$(1.80 \%)$, and rhamnose (1.40\%). Similar results were also found in the crude polysaccharides obtained from $A$. strobiliformis fruiting bodies, glucose being the major sugar, followed by galactose, along with trace amounts of mannose, and xylose [38]. The major sugar content was slightly different from that of the polysaccharide from $A$. caesarea, consisting of glucose, and xylose [39]. It has been reported that mushroom polysaccharides from different species, sources, and growing conditions have different sugar compositions [40].

Table 2. Extraction methods, characterisation, and bioactivities of polysaccharide from edible mushroom of A. hemibapha subspecies javanica.

\begin{tabular}{|c|c|c|c|}
\hline \multirow[b]{2}{*}{ Component } & \multicolumn{3}{|c|}{ Polysaccharides } \\
\hline & MP & MPF1 & MPF2 \\
\hline Yield (\%) & $4.90^{x}$ & $57.3^{y}$ & $42.7^{y}$ \\
\hline Total carbohydrate (\% db) & $87.8 \pm 2.64^{b}$ & $93.2 \pm 0.12^{\mathrm{a}}$ & $83.5 \pm 0.50^{\mathrm{c}}$ \\
\hline Protein $(\% \mathrm{db})$ & $6.80 \pm 0.17^{b}$ & $5.40 \pm 0.20^{\mathrm{c}}$ & $7.20 \pm 0.09^{a}$ \\
\hline Sulphate $(\% \mathrm{db})$ & $5.40 \pm 0.20^{b}$ & $1.40 \pm 0.03^{c}$ & $9.30 \pm 0.10^{\mathrm{a}}$ \\
\hline Uronic acid (\%) & - & - & - \\
\hline \multicolumn{4}{|l|}{ Monosaccharide content (\%) } \\
\hline Rhamnose & $1.40 \pm 0.05^{b}$ & $2.70 \pm 0.03^{\mathrm{a}}$ & $0.80 \pm 0.10^{\mathrm{c}}$ \\
\hline Arabinose & $1.80 \pm 0.08^{b}$ & $4.70 \pm 0.08^{\mathrm{a}}$ & $0.30 \pm 0.02^{c}$ \\
\hline Xylose & $1.10 \pm 0.10^{b}$ & $2.50 \pm 0.20^{\mathrm{a}}$ & - \\
\hline Mannose & $3.30 \pm 0.30^{\mathrm{a}}$ & $1.40 \pm 0.10^{b}$ & $0.30 \pm 0.00^{\mathrm{c}}$ \\
\hline Glucose & $85.5 \pm 0.50^{b}$ & $79.6 \pm 1.35^{c}$ & $98.4 \pm 0.46^{\mathrm{a}}$ \\
\hline Galactose & $6.80 \pm 2.64^{b}$ & $9.10 \pm 0.00^{\mathrm{a}}$ & $0.20 \pm 0.02^{\mathrm{c}}$ \\
\hline \multicolumn{4}{|l|}{ Molecular properties } \\
\hline Samples & $\mathrm{MW} \times 10^{3}(\mathrm{~g} / \mathrm{mol})$ & \multicolumn{2}{|c|}{$\operatorname{Rg}(\mathrm{nm})$} \\
\hline $\mathrm{MP}$ & $479.4 \pm 14.7^{a}$ & \multicolumn{2}{|c|}{$148.2 \pm 10.0^{\mathrm{a}}$} \\
\hline MPF1 & $219.2 \pm 14.8^{b}$ & \multicolumn{2}{|c|}{$132.3 \pm 6.4^{b}$} \\
\hline MPF2 & $104.0 \pm 13.1^{\mathrm{c}}$ & \multicolumn{2}{|c|}{$173.1 \pm 5.9^{\mathrm{c}}$} \\
\hline
\end{tabular}

$\bar{x}$ Yield, (weight of crude/weight of sample powder) $\times 100 .{ }^{y}$ Yield, (weight of fractions/weight of crude injected into column) $\times 100$. \% db, \% dry basis. Abbreviations: MW, mean average molecular weight, and $R g$, radius of gyration. Different letters indicate significant differences $(p<0.05)$ among the groups in each row for total carbohydrate and monosaccharide content, and each column for molecular properties.

The MPs were further separated using anion-exchange chromatography to obtain mucilage polysaccharide fractions (MPFs). The MP was eluted with distilled water to obtain a neutral polysaccharide, and subsequently eluted with a stepwise $\mathrm{NaCl}$ gradient (0.5-2.0 M). In total, two major fractions were identified as MPF1, and MPF2, with yields of $57.3 \%$, and $42.7 \%$, respectively (Figure 1a). The yield percentage was calculated based on $100 \%$ of the MP using the following formula as given below Table 2.

MPF1, and MPF2 mainly consisted of carbohydrates (93.2\%, and 83.5\%), and MPF1 contained a trace amount of proteins $(5.40 \%)$, and sulphates $(1.40 \%)$. The small number of sulphates with the weakest ionic interactions started to elute from the column first by distilled water. However, a trace number of proteins (5.40\%) contained in MPF1 might not have been a negative charge of the protein, where they cannot bind to the positively charged matrix on the anion exchangers. In contrast, MPF2 had numbers of protein (7.20\%), and sulphates $(9.30 \%$ ) (Table 2). It was eluted with $0.5 \mathrm{M} \mathrm{NaCl}$. The elution that was done by $0.5 \mathrm{M} \mathrm{NaCl}$ might be from the tightness of the binding between the negative charges of sulphates, and the positively charged matrix in the anion-exchange column.

MPF1, and MPF2 mainly contained glucose as the major sugar unit. Both fractions contained small amounts of galactose, mannose, xylose, arabinose, and rhamnose. The polysaccharides from other mushroom species, such as Polyporus rhinocerus, contain high levels of glucose $(87.8 \%)$, and mannose $(12.2 \%)$ [41]. However, the fractionated polysaccharide (VHPI-a) from Volvariella volvacea consists of only glucose [27]. 
(a)

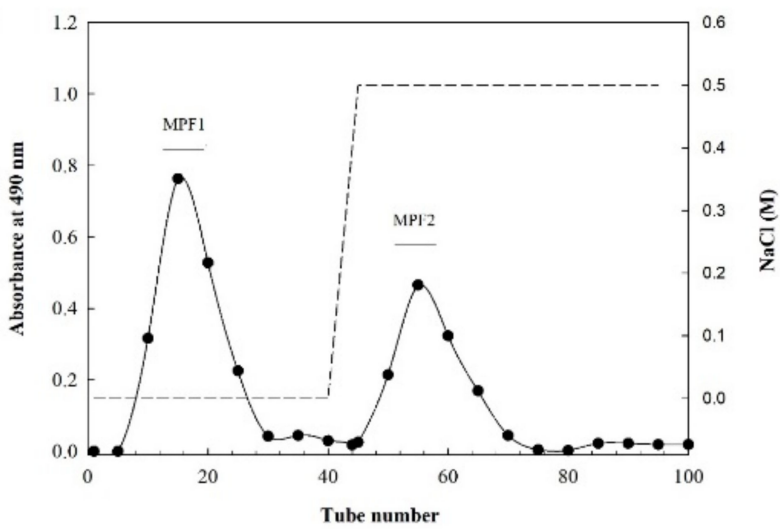

(c)

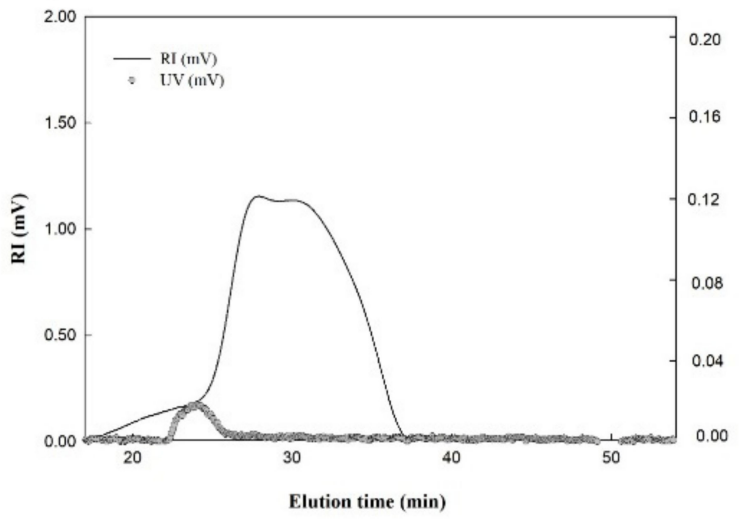

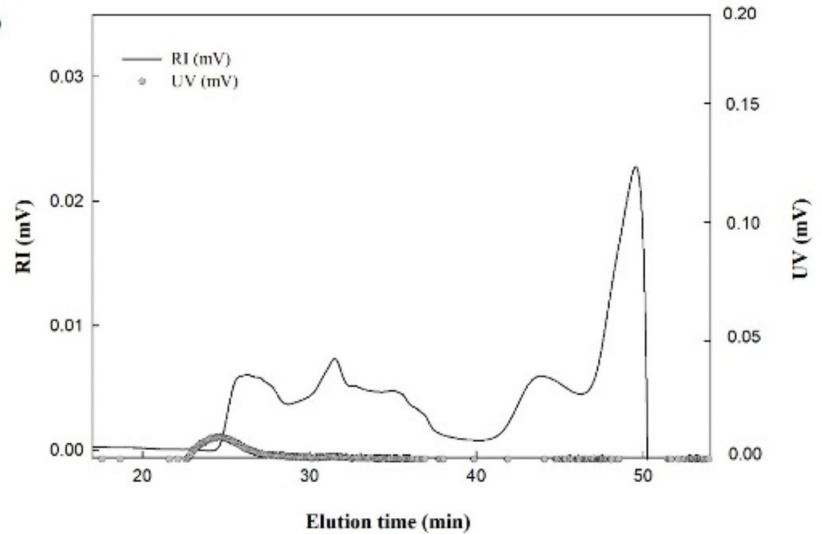

(d)

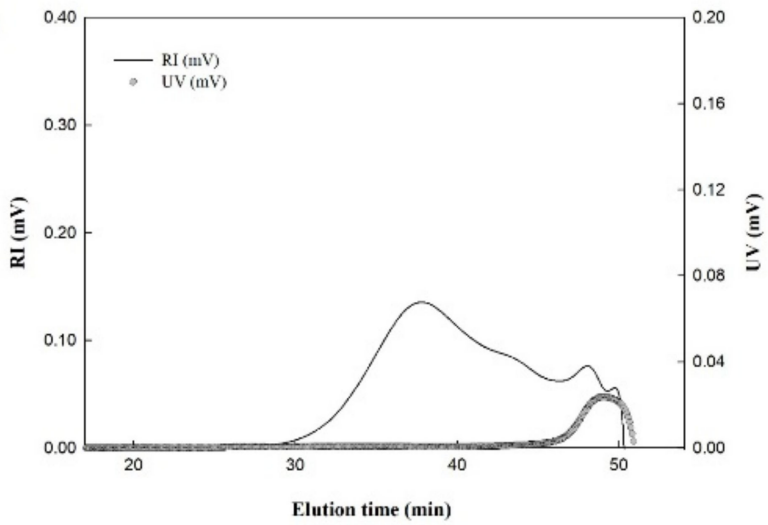

Figure 1. Elution profile of fractionated polysaccharide from A. hemibapha subspecies javanica through anion-exchange chromatography column (a). UV and RI chromatograms of MP (b), fraction MPF1 (c), and fraction MPF2 by using the size-exclusion chromatography column (d).

\subsection{Molecular Characteristics of MPS, and MPFs}

The chromatograms from the RI, and UV detectors for the MPs, and MPFs are shown in Figure $1 b-d$. The MPs were eluted from the SEC column at elution times from 25 to $50 \mathrm{~min}$, with broad scattering peaks from the RI chromatogram, indicating their heterogeneous polymer distributions (Figure 1b). As shown in the UV chromatogram, proteins were detected at an elution time of 25 to $28 \mathrm{~min}$. The MW value of the peaks obtained from the multi-angle laser light scattering technique was $479.4 \times 10^{3} \mathrm{~g} / \mathrm{mol}$ (Table 2). The approximate size of the crude mucilage polymer was obtained by the $R g$ calculated from the peaks (Table 2). The $R g$ value of the peaks of crude MP was $148.2 \mathrm{~nm}$.

The chromatogram (RI) of fraction MPF1 showed a major peak at an elution time of 25 to $35 \mathrm{~min}$, and no UV chromatogram was shown for MPF1 (Figure 1c), which is in good agreement with the protein content presented in Table 2 . The MW was $219.2 \times 10^{3} \mathrm{~g} / \mathrm{mol}$, and the $R g$ value was $132.3 \mathrm{~nm}$. For fraction MPF2, the RI, and UV chromatograms were shown to be in the same direction (Figure 1d), RI revealing elution times of 30 to $50 \mathrm{~min}$, and UV showing an elution time of 47 to $50 \mathrm{~min}$. The MW, and $R g$ values were $104.0 \times$ $10^{3} \mathrm{~g} / \mathrm{mol}$, and $173.1 \mathrm{~nm}$, respectively (Table 2 ).

Thus, we obtained two low molecular weight fractions (MPF1; $219.2 \times 10^{3} \mathrm{~g} / \mathrm{mol}$, and MPF2; $\left.104.0 \times 10^{3} \mathrm{~g} / \mathrm{mol}\right)$ from MP $\left(479.4 \times 10^{3} \mathrm{~g} / \mathrm{mol}\right)$. Similarly, the low molecular weight fractions were obtained after fractionation by using anion-exchange chromatography $[42,43]$. As reported, the polysaccharides extracted from Myriophyllum spicatum L., and fractionated using the DEAE Sepharose fast flow column exhibited the crude MW, and two fractions as 529.0, 497.8, and $217.4 \times 10^{3} \mathrm{~g} / \mathrm{mol}$ [44]. Moreover, the polysaccharide from Gracilaria rubra (GRPS), and its three purified fractions GRPS-1-1, GRPS-2-1, and GRPS-3-2 
were obtained through water extraction, and ion chromatographic purification. The three fractions showed the MW, 1310, 691, and $923 \times 10^{3} \mathrm{~g} / \mathrm{mol}$ [45]. Moreover, it is also reported in the literature that polysaccharides with MW $>200 \times 10^{3} \mathrm{~g} / \mathrm{mol}$ are good immunogens, and demonstrate immunostimulatory properties. Lentinan, and schizophyllan have a MW of 300-800 and $450 \times 10^{3} \mathrm{~g} / \mathrm{mol}$, respectively [46].

\subsection{Immunomodulatory Activity of MPs, and MPFs}

The effects of MPs, and MPFs on immunomodulation were tested in RAW264.7 murine macrophage cells. Macrophage cells are well known to be closely related to the response of both the innate, and adaptive immune systems by releasing NO or several cytokines such as IL-6, IL-10, IL-1 $\beta$, and TNF- $\alpha$ [30]. Generally, mushroom $\beta$-glucans, and/or $\alpha$-glucans with the structure linear, and/or branched effect on the immune system function mainly through macrophages stimulation. These $\beta /$ or $\alpha$-glucans could bind to specific receptors such as Toll-like receptors (TLRs) of the macrophage to trigger the immune response by releasing nitric oxide $(\mathrm{NO})$, and producing various cytokines such as TNF- $\alpha$, IL-6, and IL-1 $\beta$ [27]. The cell proliferation stimulated by the polysaccharides (MP, MPF1, and MPF2) was determined in order to evaluate the cytotoxic effect at a concentration of 50-200 $\mathrm{\mu g} / \mathrm{mL}$ (Figure 2a). Incubation of the macrophage cells with the crude extract, and fractions (MP, MPF1, and MPF2) considerably improved proliferation of the RAW264.7 cells compared to the control, which suggests that the crude extract, and fractions are non-toxic to the cells at the tested concentrations. The biological mediators, such as NO, released from the RAW264.7 cells by MP, MPF1, and MPF2 at concentrations of $50-200 \mu \mathrm{g} / \mathrm{mL}$ are presented in Figure $2 \mathrm{~b}$. Approximately 7.37-17.4 $\mu \mathrm{M}$ NO was released by the MP at a concentration of 50-200 $\mu \mathrm{g} / \mathrm{mL}$. Similarly, MPF1 stimulated the secretion of NO to around 19.0-24.1 $\mu \mathrm{M}$. Fraction MPF2 exhibited the highest NO production: $>27 \mu \mathrm{M}$ at all concentrations. The NO production induced by treatment with MPF2 was comparable to that for the positive control (LPS; $1 \mu \mathrm{g} / \mathrm{mL}$ ), suggesting its strong stimulation of macrophage cells. The NO production of the RAW264.7 cells was in agreement with that reported for treatment with $V$. volvacea in the range of 7.76$32.5 \mu \mathrm{g} / \mathrm{mL}$ [27], and 2-13 $\mu \mathrm{g} / \mathrm{mL}$ for Armillariella tabescens [47]. It has been reported that the key factors affecting immune activity, such as MW, polymer structure, and chemical compositions, which include protein or sulphate affect immunostimulatory properties. As reported by Surayot et al. (2014), the low MW of polysaccharides from lactic acid bacteria provides better immunostimulation of immune cells [48]. In addition, the sulphate polysaccharides from Hypsizigus marmoreus, and Cladophora glomerata Kützing exhibit strong production of NO, and various cytokines $[33,49]$. In this study, MPF2 had a lower MW than MP, and MPF1, which seems to be related to NO stimulation. The correlation between the structure, and biological activity of polysaccharides is too complicated to elucidate. Future research studies on the structure, and activity relationship are currently being conducted. 
(a)

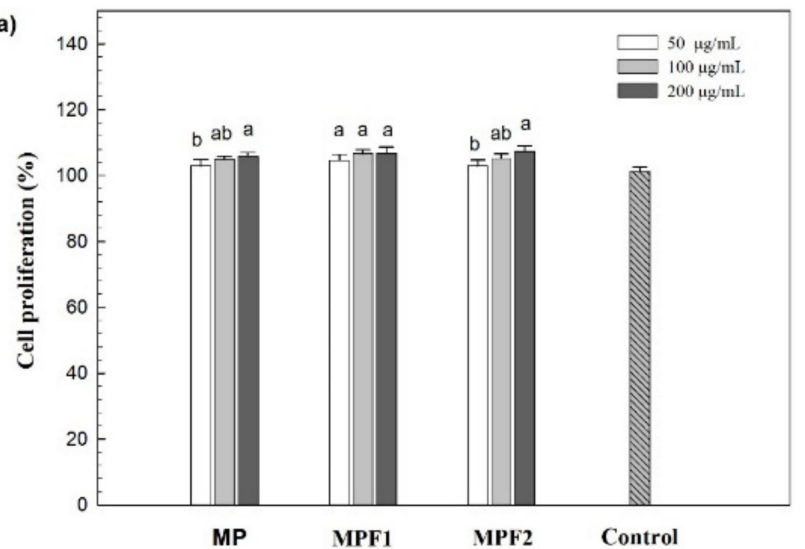

(b)

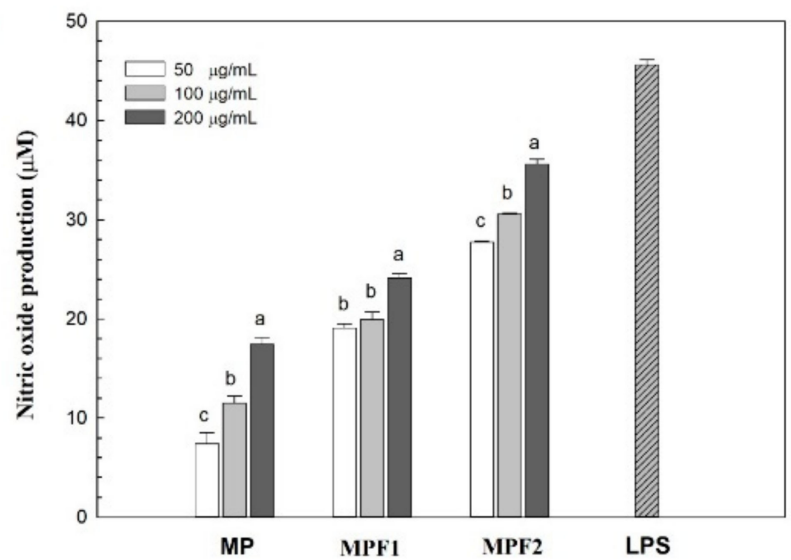

Figure 2. Effect of MP, MPF1, and MPF2 on RAW264.7 cell activity. RAW264.7 cell proliferation with different polysaccharide treatment concentrations. Medium alone was used as a control (a). Nitric oxide (NO) production, and the medium alone was used as a control, while LPS was used as the positive control (b). Values are presented as mean \pm standard deviation $(n=3)$. Different letters $a, b, c$ indicate significant differences $(p<0.05)$ among the groups in concentration.

\subsection{Effect of MP, and MPF Stimulation on Cytokine mRNA Expression}

The mRNA expression of inducible nitric oxide synthase (iNOS) in the RAW264.7 cells induced by MP, MPF1, and MPF2 was determined by RT-PCR. As shown in Figure $3 a, b$, after the addition of the sample, cells treated with MPF2 showed a strong band, which indicated the marked induction of iNOS gene expression. Therefore, the increased levels of NO released from the RAW264.7 cells might be associated with enhanced mRNA, and protein expression of iNOS that appeared to be upregulated in the RAW264.7 cells through activation by the fraction MPF2. The mRNA expression of pro-inflammatory cytokines, including IL-1 $\beta$, TNF- $\alpha$, and IL-6, in the RAW264.7 cells is shown in Figure 3a,b. The mRNA expression of IL- $1 \beta$, TNF- $\alpha$, and IL- 6 induced by MPF2 could stimulate the RAW264.7 cells to produce a considerable amount of cytokines. In this research, IL-10, and IL-12 were also noticed after treatment with MP, and MPFs to conquer excess production of pro-inflammatory cytokines. Therefore, the polysaccharide of $A$. hemibapha subspecies javanica might be capable of modulating the host immune system by releasing various cytokines. Similar results were seen in polysaccharides from C. cibarius, which stimulated RAW264.7 cells by secretion of TNF- $\alpha$, IL-1 $\beta$, IL-2, IL-6, IL-10, and IL-12 [16]. 
(a)

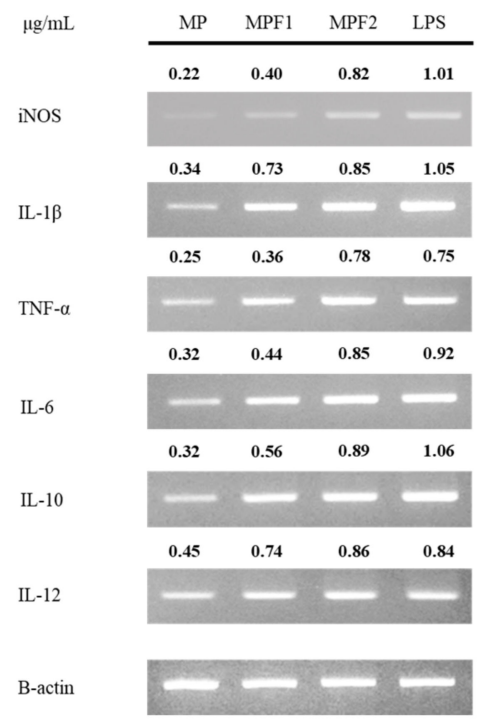

(c)

MP MPF1 MPF2 LPS Control

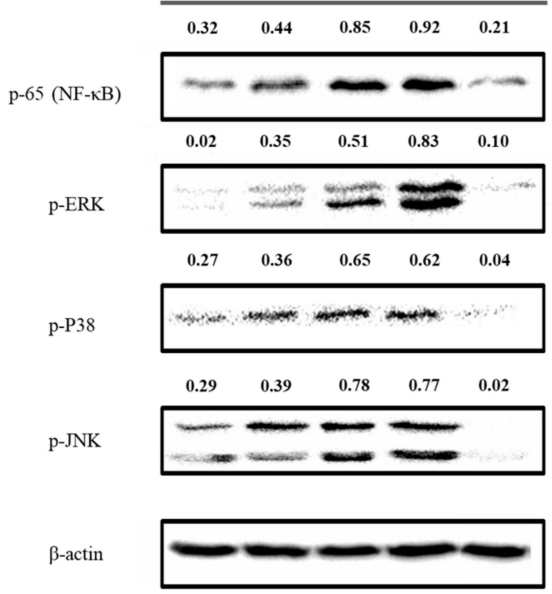

(b)

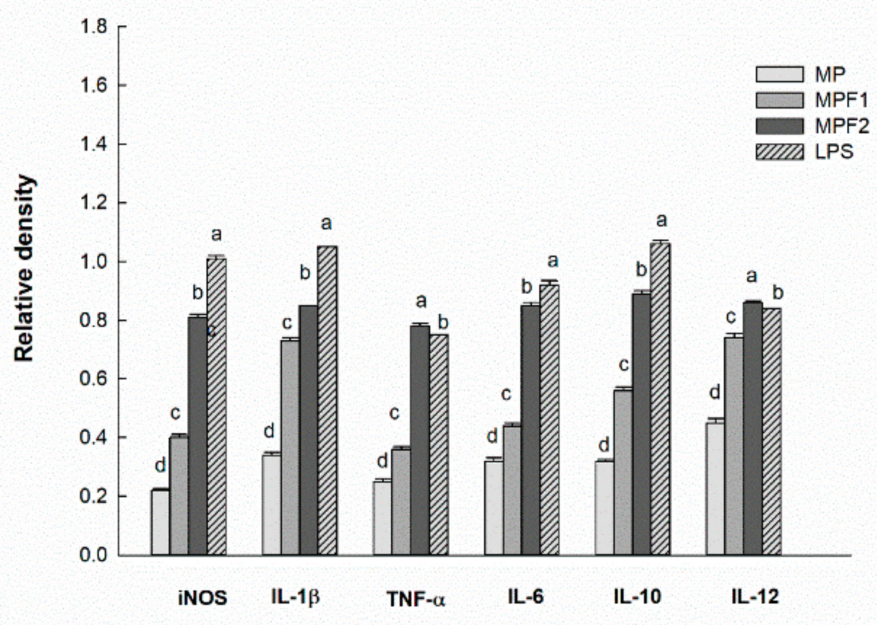

(d)

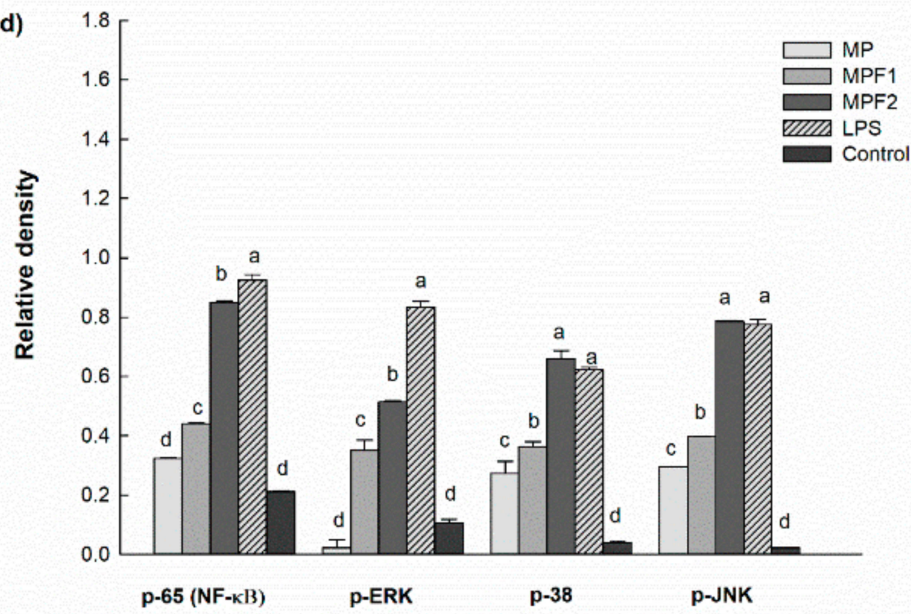

Figure 3. Effects of MP, MPF1, and MPF2 from A. hemibapha subspecies javanica on cytokine mRNA expression in RAW264.7 cells (a), and the relative band intensity (b). Phosphorylation of p65, ERK, P38, and JNK by MP, MPF1, and MPF2 (c), and the relative band intensity $(\mathbf{d})$. Different letters $a, b, c, d$ indicate a significant difference $(p<0.05)$ among the MP, MPF1, and MPF2.

\subsection{Immunomodulatory Mechanism by Western Blot Analysis}

Further study was performed to elucidate the mechanism by which the polysaccharides stimulate the production of inflammatory mediators such as cytokines, and NO in macrophage cells; thus, nuclear factor-kappa B (NF-kB), and MAPK activation was investigated. NF- $\kappa \mathrm{B}$ is a major transcription factor, and regulates many target genes, playing an important role in immunomodulatory activity. In the activated condition, phosphorylation of the inhibitor $(\mathrm{I}-\mathrm{kB})$ results in NF- $\mathrm{BB}$ translocation to the nucleus. After being translocated to the nucleus, NF- $\mathrm{kB}$ starts the transcription of the target genes, which encode various cytokines, and inducible enzymes. As shown in Figure 3c,d, MP, MPF1, and MPF2 were tested at $200 \mu \mathrm{g} / \mathrm{mL}$. The phosphorylation of NF- $\mathrm{BB}$ (p65) was significantly higher in treatments with MPF2 than MP, and MPF1, indicating that the MPF2 induces the translocation of NF- $\mathrm{KB}$ (p65) from the cytosol to the nucleus, which results in the activation of RAW264.7 cells. In addition, the MAPK pathways play a role in the regulation of immune responses. MAPK members such as ERK, JNK, and p-38 are shown in Figure 3. Treatment with MPF2 
strongly induced the phosphorylation of ERK, p38, and JNK compared with the control. Overall, the polysaccharides of $A$. hemibapha subspecies javanica stimulated the RAW264.7 cells via activation of the NF- $\mathrm{B}$, and MAPK pathways. This results in agreement with the report by Cui et al. (2020) regarding the fact that the polysaccharide (glucan) from the fruiting body of $V$. volvacea also activates macrophage cells via the MAPK pathways [27].

\subsection{MPF2 on Binding Receptors}

It has been found that polysaccharide from mushroom activates macrophages through the activation of pathogen-associated molecular patterns (PAMPs) by pattern recognition receptors (PRRs) on the surface of cells. Some evidence shows that the polysaccharides might bind to cell surface receptors such as complement receptor 3 (CR3), and toll-like receptor 4 (TLR4) [50]. In the present study, the role of TLR4, and CR3 was investigated, as shown in Figure 4. The RAW264.7 cells were pre-treated with $30 \mu \mathrm{g} / \mathrm{mL}$ of anti-TLR4, and anti-CR3 for $2 \mathrm{~h}$; after blocking the binding receptors, the level of NO production was significantly decreased by anti-TLR4 but not anti-CR3, therefore suggesting that the polysaccharide from $A$. hemibapha subspecies javanica (MPF2) stimulated the RAW264.7 cells via activation of the NF- $\mathrm{B}$, and MAPK pathways through the binding of TLR4 receptors (Figure S1). These results agree with the study conducted by Hsu et al. (2004) who showed that the extract of Ganoderma lucidum polysaccharides shows immunomodulatory activity by stimulating the expression of cytokines via the recognition of TLR4 [51].

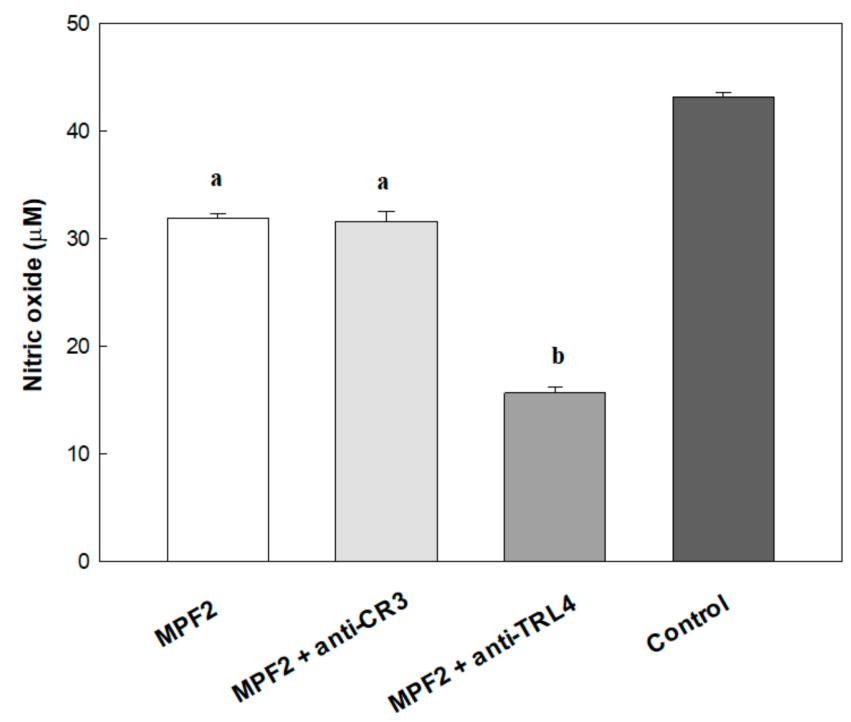

Figure 4. Nitric oxide (NO) production in the antibody neutralisation assay. RAW264.7 cells were pre-incubated with antibodies of the receptors for $2 \mathrm{~h}$ before stimulation with MPF2. LPS was used as the positive control. Data are presented as mean \pm standard deviation. Different letters a,b indicate a significant difference $(p<0.01)$ between polysaccharides (MPF2), MPF2 + anti-CR3 Ab, and MPF2 + anti-TLR4 Ab.

\subsection{Structural Analysis of MPF2}

The most immunoenhancing polysaccharide (MPF2) was subjected to structural analysis by GC-MS, and 1D-NMR spectral analysis to elucidate the glycosidic linkages. The glycosidic linkages of MPF2 were elucidated by methylation analysis as shown in Table 3. The most abundant components of the partially methylated, and acetylated derivatives were 2,3,4-trimethyl-Glcp, which implies that the backbone of the MPF2 fraction was mainly glucose connected by $(1 \rightarrow 6)$ linkages (Figure $5 a)$. The absolute configuration of the monosaccharide indicated that glucose is present in the D configuration. 
Table 3. Glycosidic linkage analysis of the most immunostimulating polysaccharide (MPF2) from A. hemibapha subspecies javanica.

\begin{tabular}{ccccc}
\hline Methylation Sugar & $\begin{array}{c}\text { Retention Time } \\
\text { (min) }\end{array}$ & Mass Fraction (m/z) & Glycosidic Linkage & Peak Area (\%) \\
\hline \multirow{2}{*}{$2,3,4,6-\mathrm{Me}_{4}$-Glc } & 9.52 & $\begin{array}{l}43,59,71,87,102,118, \\
129,145,162,174,205\end{array}$ & Glc- $(1 \rightarrow$ & 1.7 \\
$2,3,4-\mathrm{Me}_{3}-\mathrm{Glc}$ & 11.8 & $\begin{array}{l}43,59,71,87,102,118, \\
129,162,174,189,233\end{array}$ & $\rightarrow 6)-$ Glc- $(1 \rightarrow$ & 98.3 \\
\hline
\end{tabular}

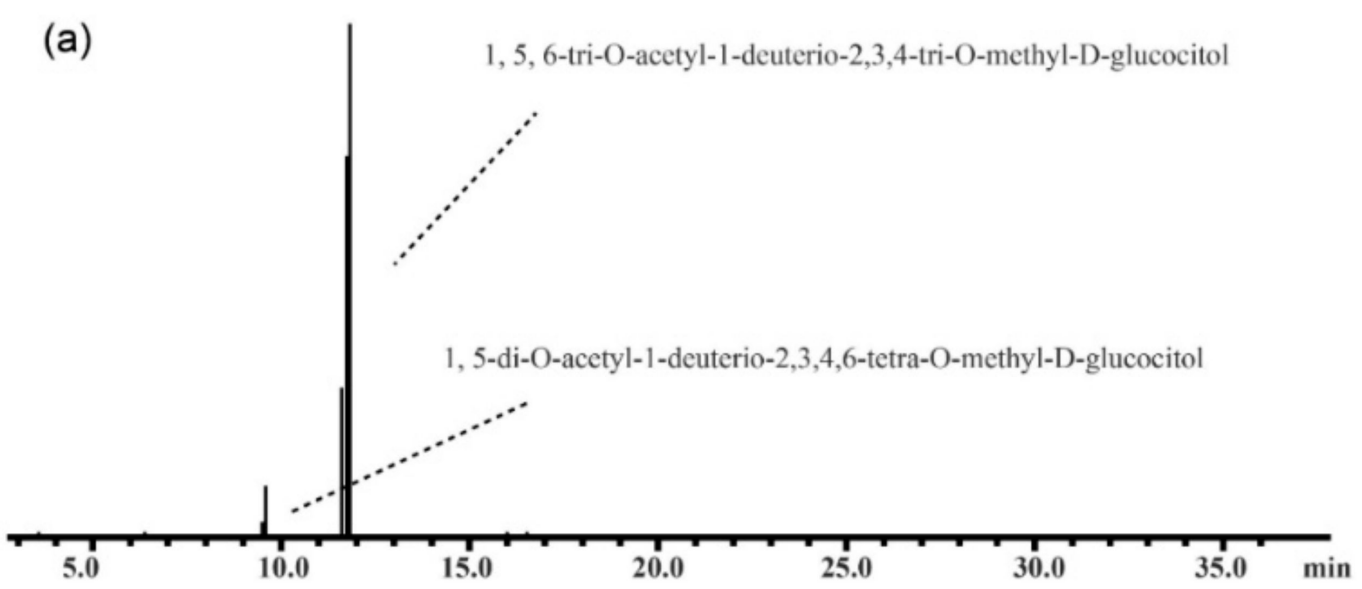

(b)

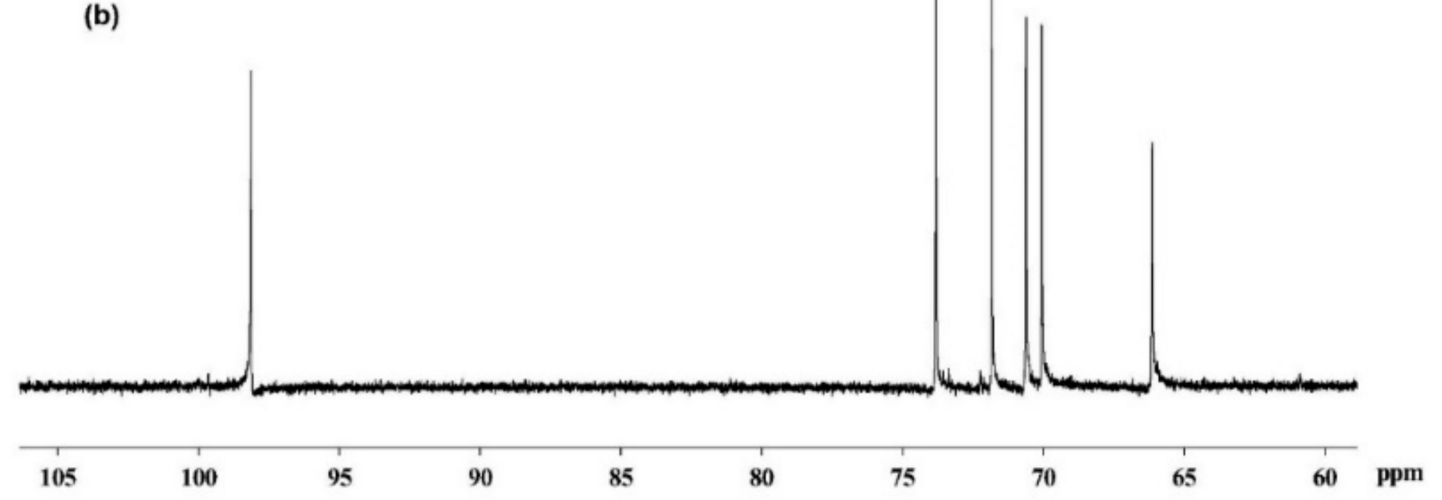

Figure 5. Cont. 

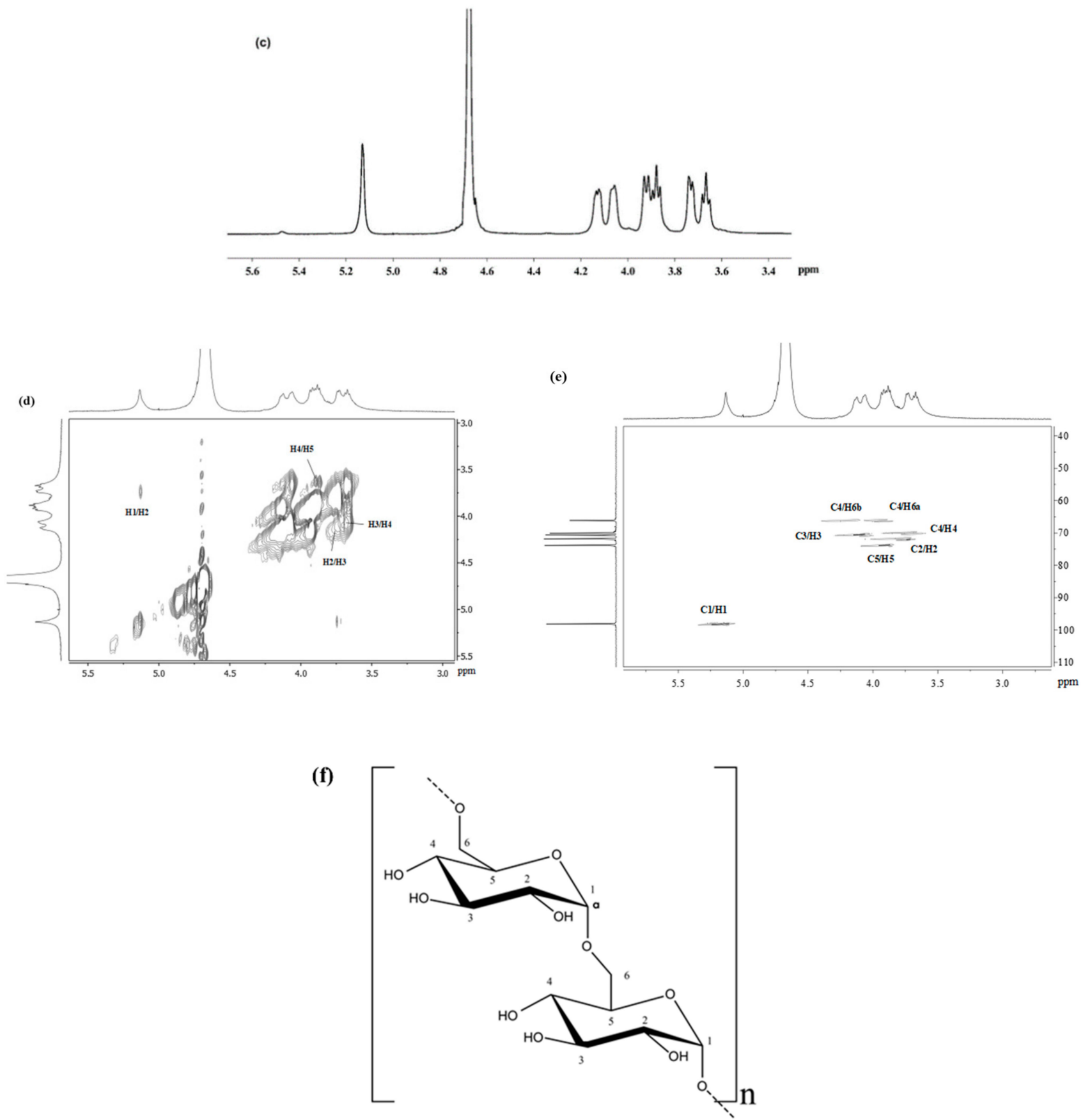

Figure 5. GC-MS spectra (a), ${ }^{13} \mathrm{C}-\mathrm{NMR}$ spectra (b), ${ }^{1} \mathrm{H}-\mathrm{NMR}$ spectra (c), COSY-NMR spectra (d), HMQC-NMR spectra (e), and the main backbone of MPF2 (f) from A. hemibapha subspecies javanica.

Furthermore, glycosidic linkages of MPF2 were confirmed by 1D, and 2D-NMR analysis. As shown in Figure 5b,c, and Table 4, only one anomeric signal at 97.2, and $5.19 \mathrm{ppm}$ appeared in the ${ }^{13} \mathrm{C}$ NMR, and ${ }^{1} \mathrm{H}$ spectra. The ${ }^{1} \mathrm{H}$ anomeric chemical shift at $5.19 \mathrm{ppm}$ had a small value of the ${ }^{3} \mathrm{~J}_{1,2}$ coupling constant ( 3.04), indicating that it is an $\alpha$-anomeric configuration. The other ${ }^{1} \mathrm{H}$ signals using the COSY spectrum (Figure $5 \mathrm{~d}$ ) were at 3.75, 3.98, 3.72, 4.14, and 3.95/4.19, which were ascribed as H-2, H-3, H-4, H-5, and $\mathrm{H}-6 \mathrm{a} / \mathrm{b}$, respectively. Conversely, the other carbon signals (Figure $5 \mathrm{e}$ ) were assigned by the HMQC spectrum, marked at 72.3, 70.7, 70.0, 74.1, and 66.3 for C-2, C-3, C-4, C-5, and C-6, respectively. The C-6 peak showed a downfield shift of $66.3 \mathrm{ppm}$ due to the effect of glycosylation, which is comparable to the resonance of a glucose standard [52]. Thus, MPF2 is an $\alpha-(1 \rightarrow 6)$-linked-glucopyranosyl moiety. After the comprehensive methy- 
lation analysis, and NMR analysis, it can thus be concluded that the backbone of MPF2 is $\alpha$-(1 $\rightarrow 6$ )-linked-glucopyranosyl (Figure $5 \mathrm{f})$. The glycosidic linkages were similarly studied in polysaccharides from the mushroom $A$. tabescens, exhibiting a main backbone of $\alpha-(1 \rightarrow 6)$-linked-glucan [47]. In contrast, the structure of polysaccharides from mushrooms from other species are of different types $[28,53]$.

Table 4. ${ }^{1} \mathrm{H}$, and ${ }^{13} \mathrm{C}$ NMR spectral data of the most immunostimulating polysaccharide (MPF2) from A. hemibapha subspecies javanica.

\begin{tabular}{ccccccc}
\hline Residue & H-1/C-1 & H-2/C-2 & H-3/C-3 & H-4/C-4 & H-5/C-5 & H-6a, H-6b/C-6 \\
\hline $\begin{array}{c}\alpha-\mathrm{D}-(1 \rightarrow 6) \\
\text { Glcp }\end{array}$ & $5.19 / 97.2$ & $3.75 / 72.3$ & $3.98 / 70.7$ & $3.72 / 70.0$ & $4.14 / 74.1$ & $3.95,4.19 / 66.3$ \\
\hline
\end{tabular}

\section{Conclusions}

The MP from A. hemibapha subspecies javanica (Corner, and Bas) was purified using a DEAE-Sepharose fast flow column. Fraction MPF2 had a homogenous molecular distribution with an average MW of $104.0 \times 10^{3} \mathrm{~g} / \mathrm{mol}$. The chemical constituents of MPF2 were primarily glucose, and a minor amount of rhamnose, arabinose, mannose, and galactose. The highest levels of NO, and pro-inflammatory cytokines were secreted from RAW264.7 cells treated with MPF2. The interaction of RAW264.7 cells with MPF2 occurred through the cell surface receptor TLR4, initiating the cascade activation of the NF- $\mathrm{KB}$, and MAPK pathways. The structural backbone of MPF2 mainly consists of $\alpha-(1 \rightarrow 6)$-linkedglucopyranosyl residues. The result of this study demonstrates the important role of MPF2 in the development of new immunostimulants for application in novel functional foods, and nutraceuticals. Further research on the binding mechanism between polysaccharides, and cell surface receptors would lead to a better understanding of the relationship between its molecular structures, functional groups attached to polysaccharide, and immunomodulation activities through investigating in vitro (macrophage, and NK cell lines), and in vivo (mice, and rats). This research is required prior to applying MPF2 in food products and determining its stability for industrial food or nutraceutical applications.

Supplementary Materials: The following are available online at https://www.mdpi.com/article/10 .3390/jof7090683/s1, Table S1: The sequences of primer used for RT-PCR, Table S2: Enhanced chemiluminescence $(E C L)$ kit, and its instructions, Figure S1: a schematic illustration for the interaction of MPF2 to TLR4.

Author Contributions: Conceptualisation, S.Y.; data curation, S.W.; funding acquisition, U.S., and P.S.; investigation, W.K., and Y.P.; methodology, S.P.; supervision, P.S.; writing-original draft, U.S.; writing-review, and editing, C.S.B., and F.J.B. All authors have read and agreed to the published version of the manuscript.

Funding: This study was fully supported by the Thailand Research Fund, and Office of the Higher Education Commission (grant number: MRG6280218), and partially received financial support from the Program Management Unit for Human Resources \& Institutional Development, Research, and Invitation, NXPO (Frontier Global Partnership for Strengthening Cutting-edge Technology, and Innovations in Materials Science (grant number: B16F640001)).

Institutional Review Board Statement: Not applicable.

Informed Consent Statement: Not applicable.

Data Availability Statement: Any additional data can be available upon request to the corresponding author. 
Acknowledgments: This study was fully supported by the Thailand Research Fund, and Office of the Higher Education Commission (grant number: MRG6280218). Phisit Seesuriyachan also acknowledges partial financial support, and/or in-kind assistance from the Program Management Unit for Human Resources \& Institutional Development, Research, and Invitation, NXPO (Frontier Global Partnership for Strengthening Cutting-edge Technology, and Innovations in Materials Science (grant number: B16F640001)), and the College of Maritime Studies, and Management, the Faculty of Engineering, and the Faculty of Agro-Industry, Chiang Mai University (CMU), Thailand.

Conflicts of Interest: The authors declare no conflict of interest.

\section{References}

1. Roselló-Soto, E.; Parniakov, O.; Deng, Q.; Patras, A.; Koubaa, M.; Grimi, N.; Boussetta, N.; Tiwari, B.K.; Vorobiev, E.; Lebovka, N.; et al. Application of non-conventional extraction methods: Toward a sustainable and green production of valuable compounds from mushrooms. Food. Eng. Rev. 2016, 8, 214-234. [CrossRef]

2. Lu, X.; Brennan, M.A.; Seventi, L.; Mason, S.; Brennan, C.S. How the inclusion of mushroom powder can affect the physicochemical characteristics of pasta. Int. J. Food Sci. Technol. 2016, 51, 2433-2439. [CrossRef]

3. Novakovic, S.; Djekic, I.; Vunduk, J.; Klaus, A.; Lorenzo, J.M.; Barba, F.J.; Tomasevic, I. An insight into in vitro antioxidant activity of Cantharellus cibarius hot water extract for the potential application in meat products. IOP Conf. Ser. Earth. Environ. Sci. 2019, 333, 012089. [CrossRef]

4. Lu, X.; Brennan, M.A.; Guan, W.; Zhang, J.; Yuan, L.; Brennan, C.S. Enhancing the nutritional properties of bread by incorporating mushroom bioactive compounds: The manipulation of the predictive glycaemic response and the phenolic properties. Foods. 2021, 10, 731. [CrossRef]

5. Cheung, P.C.K. Nutritional value and health benefits of mushrooms. In Mushrooms as Functional Foods; Cheung, P., Ed.; John Wiley \& Sons: Hoboken, NJ, USA, 2008; pp. 71-109.

6. Olatunji, O.J.; Feng, Y.; Olatunji, O.O.; Tang, J.; Wei, Y.; Ouyang, Z.; Su, Z. Polysaccharides purified from Cordyceps cicadae protects PC12 cells against glutamate-induced oxidative damage. Carbohydr. Polym. 2016, 153, 187-195. [CrossRef] [PubMed]

7. Quintero-Cabello, K.P.; Lugo-Flores, M.A.; Rivera-Palafox, P.; Silva-Espinoza, B.A.; González-Aguilar, G.A.; Esqueda, M.; Gaitán-Hernández, R.; Ayala-Zavala, J.F. Antioxidant Properties and Industrial Uses of Edible Polyporales. J. Fungi. $2021,7,196$. [CrossRef] [PubMed]

8. Xu, Z.; Yan, X.; Song, Z.; Li, W.; Zhao, W.; Ma, H.; Du, J.; Li, S.; Zhang, D. Two heteropolysaccharides from Isaria cicadae Miquel differ in composition and potentially immunomodulatory activity. Int. J. Biol. Macromol. 2018, 117, 610-616. [CrossRef]

9. Prasain, J.K. Pharmacological effects of cordyceps and its bioactive compounds. In Studies in Natural Products Chemistry; Elsevier: Amsterdam, The Netherlands, 2013; Volume 40, pp. 453-468.

10. Olawuyi, I.F.; Lee, W.Y. Structural characterization, functional properties and antioxidant activities of polysaccharide extract obtained from okra leaves (Abelmoschus esculentus). Food Chem. 2021, 354, 129437. [CrossRef]

11. Alvarado-Morales, G.; Minjares-Fuentes, R.; Contreras-Esquivel, J.C.; Montañez, J.; Meza-Velázquez, J.A.; Femenia, A. Application of thermosonication for Aloe vera (Aloe barbadensis Miller) juice processing: Impact on the functional properties and the main bioactive polysaccharides. Ultrason. Sonochem. 2019, 56, 125-133. [CrossRef]

12. Nerkar, P.P.; Gattani, S.G. Oromucosal delivery of venlafaxine by linseed mucilage based gel: In vitro and in vivo evaluation in rabbits. Arch. Pharm. Res. 2013, 36, 846-853. [CrossRef]

13. Surin, S.; Surayot, U.; Seesuriyachan, P.; You, S.G.; Phimolsiripol, Y. Antioxidant and immunomodulatory activities of sulphated polysaccharides from purple glutinous rice bran (Oryza sativa L.). Int. J. Food Sci. Technol. 2018, 53, 994-1004. [CrossRef]

14. Surin, S.; You, S.G.; Seesuriyachan, P.; Muangrat, R.; Wangtueai, S.; Jambrak, A.R.; Phongthai, S.; Jantanasakulwong, K.; Chaiyaso, T.; Phimolsiripol, Y. Optimization of ultrasonic-assisted extraction of polysaccharides from purple glutinous rice bran (Oryza sativa L.) and their antioxidant activities. Sci. Rep. 2020, 10, 10410. [CrossRef] [PubMed]

15. Rattana, T.; Saengsanga, T. Antioxidant and Anti-food Pathogen Properties in Food from Mycelium Culture of Wild Mushroom. Thai. Sc. Technol. J. 2020, 28, 2250-2260.

16. Chen, L.; Peng, X.; Lv, J.; Liao, S.; Ou, S.; Shen, Y. Purification and structural characterization of a novel water-soluble neutral polysaccharide from Cantharellus cibarius and its immunostimulating activity in RAW264.7 cells. Int. J. Polym. Sci. 2017, 2017, 1-9. [CrossRef]

17. Chen, X.; Fang, D.; Zhao, R.; Gao, J.; Kimatu, B.M.; Hu, Q.; Chen, G.; Zhao, L. Effects of ultrasound-assisted extraction on antioxidant activity and bidirectional immunomodulatory activity of Flammulina velutipes polysaccharide. Int. J. Biol. Macromol. 2019, 140, 505-514. [CrossRef] [PubMed]

18. Qi, W.; Zhou, X.; Wang, J.; Zhang, K.; Zhou, Y.; Chen, S.; Nie, S.; Xie, M. Cordyceps sinensis polysaccharide inhibits colon cancer cells growth by inducing apoptosis and autophagy flux blockage via mTOR signaling. Carbohydr. Polym. 2020, 237, 116113. [CrossRef]

19. Shu, X.; Zhang, Y.; Jia, J.; Ren, X.; Wang, Y. Extraction, purification and properties of water-soluble polysaccharides from mushroom Lepista nuda. Int. J. Biol. Macromol. 2019, 128, 858-869. [CrossRef] 
20. Song, X.; Ren, Z.; Wang, X.; Jia, L.; Zhang, C. Antioxidant, anti-inflammatory and renoprotective effects of acidic-hydrolytic polysaccharides by spent mushroom compost (Lentinula edodes) on LPS-induced kidney injury. Int. J. Biol. Macromol. 2020, 151, 1267-1276. [CrossRef] [PubMed]

21. Wang, J.; Nie, S.; Kan, L.; Chen, H.; Cui, S.W.; Phillips, A.O.; Phillips, G.O.; Xie, M. Comparison of structural features and antioxidant activity of polysaccharides from natural and cultured Cordyceps sinensis. Food Sci. Biotechnol. 2017, 26, 55-62. [CrossRef]

22. Wang, Y.; Tian, Y.; Shao, J.; Shu, X.; Jia, J.; Ren, X.; Guan, Y. Macrophage immunomodulatory activity of the polysaccharide isolated from Collybia radicata mushroom. Int. J. Biol. Macromol. 2018, 108, 300-306. [CrossRef]

23. Zhang, K.; Liu, Y.; Zhao, X.; Tang, Q.; Dernedde, J.; Zhang, J.; Fan, H. Anti-inflammatory properties of GLPss58, a sulfated polysaccharide from Ganoderma lucidum. Int. J. Biol. Macromol. 2018, 107, 486-493. [CrossRef] [PubMed]

24. Mapoung, S.; Umsumarng, S.; Semmarath, W.; Arjsri, P.; Thippraphan, P.; Yodkeeree, S. Skin Wound-Healing Potential of Polysaccharides from Medicinal Mushroom Auricularia auricula-judae (Bull.). J. Fungi. 2021, 7, 247. [CrossRef] [PubMed]

25. Chakraborty, I.; Sen, I.K.; Mondal, S.; Rout, D.; Bhanja, S.K.; Maity, G.N.; Maity, P. Bioactive polysaccharides from natural sources: A review on the antitumor and immunomodulating activities. Biocatal. Agric. Biotechnol. 2019, 22, 101425. [CrossRef]

26. Maity, P.; Sen, I.K.; Maji, P.K.; Paloi, S.; Devi, K.S.P.; Acharya, K.; Maiti, T.K.; Islam, S.S. Structural, immunological, and antioxidant studies of $\beta$-glucan from edible mushroom Entoloma lividoalbum. Carbohydr. Polym. 2015, 123, 350-358. [CrossRef] [PubMed]

27. Cui, F.; Jiang, L.; Qian, L.; Sun, W.; Tao, T.; Zan, X.; Yang, Y.; Wu, D.; Zhao, X. A macromolecular $\alpha$-glucan from fruiting bodies of Volvariella volvacea activating RAW264.7 macrophages through MAPKs pathway. Carbohydr. Polym. 2020, 230, 115674. [CrossRef]

28. Ruthes, A.C.; Carbonero, E.R.; Córdova, M.M.; Baggio, C.H.; Sassaki, G.L.; Gorin, P.A.; Santos, A.R.; Iacomini, M. Fucomannogalactan and glucan from mushroom Amanita muscaria: Structure and inflammatory pain inhibition. Carbohydr. Polym. 2013, 98, 761-769. [CrossRef]

29. Vetvicka, V.; Yvin, J.C. Effects of marine $\beta-1,3$ glucan on immune reactions. Int. Immunopharmacol. 2004, 4, 721-730. [CrossRef]

30. Tabarsa, M.; Karnjanapratum, S.; Cho, M.; Kim, J.K.; You, S.G. Molecular characteristics and biological activities of anionic macromolecules from Codium fragile. Int. J. Biol. Macromol. 2013, 59, 1-12. [CrossRef]

31. Cao, R.A.; Lee, Y.; You, S.G. Water soluble sulfated-fucans with immune-enhancing properties from Ecklonia cava. Int. J. Biol. Macromol. 2014, 67, 303-311. [CrossRef]

32. Surayot, U.; Lee, J.H.; Park, W.; You, S.G. Structural characteristics of polysaccharides extracted from Cladophora glomerata Kützing affecting nitric oxide releasing capacity of RAW264.7 cells. Carbohydr. Diet. Fibre. 2016, 7, 26-31. [CrossRef]

33. Surayot, U.; Lee, J.H.; Kanongnuch, C.; Peerapornpisal, Y.; Park, W.; You, S.G. Structural characterization of sulfated arabinans extracted from Cladophora glomerata Kützing and their macrophage activation. Biosci. Biotechnol. Biochem. 2016, 80, 972-982. [CrossRef] [PubMed]

34. Surayot, U.; Wang, J.; Lee, J.H.; Kanongnuch, C.; Peerapornpisal, Y.; You, S.G. Characterization and immunomodulatory activities of polysaccharides from Spirogyra neglecta (Hassall) Kützing. Biosci. Biotechnol. Biochem. 2015, 79, 1644-1653. [CrossRef]

35. Yelithao, K.; Surayot, U.; Lee, C.; Palanisamy, S.; Prabhud, N.M.; Lee, J.H.; You, S.G. Studies on structural properties and immune-enhancing activities of glycomannans from Schizophyllum commune. Carbohydr. Polym. 2019, 218, 37-45. [CrossRef] [PubMed]

36. Surayot, U.; Yelithao, K.; Tabarsa, M.; Lee, D.H.; Palanisamy, S.; Marimuthu Prabhu, N.; Lee, J.; You, S.G. Structural characterization of a polysaccharide from Certaria islandica and assessment of immunostimulatory activity. Process Biochem. 2019, 83, $214-221$. [CrossRef]

37. Palanisamy, S.; Vinosha, M.; Marudhupandi, T.; Rajasekar, P.; Prabhu, N.M. Isolation of fucoidan from Sargassum polycystum brown algae: Structural characterization, in vitro antioxidant and anticancer activity. Int. J. Biol. Macromol. 2017, 102, 405-412 [CrossRef]

38. Karaman, M.; Janjušević, L.; Jakovljević, D.; Šibul, F.; Pejin, B. Anti-hydroxyl radical activity, redox potential and anti-AChE activity of Amanita strobiliformis polysaccharide extract. Nat. Prod. Res. 2019, 33, 1522-1526. [CrossRef]

39. Zhu, Y.; Ding, X.; Wang, M.; Hou, Y.; Hou, W.; Yue, C. Structure and antioxidant activity of a novel polysaccharide derived from Amanita caesarea. Mol. Med. Rep. 2016, 14, 3947-3954. [CrossRef]

40. Percival, E.L.; McDowell, R.H. Chemistry and Enzymology of Marine Algal Polysaccharides; Academic Press: London, UK; New York, NY, USA, 1967.

41. Liu, C.; Choi, M.W.; Li, X.; Cheung, P.C.K. Immunomodulatory effect of structurally-characterized mushroom sclerotial polysaccharides isolated from Polyporus rhinocerus on human monoctyes THP-1. J. Funct. Foods. 2018, 41, 90-99. [CrossRef]

42. Tabarsa, M.; You, S.G.; Dabaghian, E.H.; Surayot, U. Water-soluble polysaccharides from Ulva intestinalis: Molecular properties, structural elucidation and immunomodulatory activities. J. Food Drug Anal. 2017, 26, 599-608. [CrossRef] [PubMed]

43. Lee, J.Y.; Li, C.; Surayot, U.; Yelithao, K.; Lee, S.M.; Park, W.J.; Tabarsa, M.; You, S.G. Molecular structures, chemical properties and biological activities of polysaccharide from Smilax glabra rhizome. Int. J. Biol. Macromol. 2018, 120, 1726-1733. [CrossRef] [PubMed]

44. Alavi, M.; Tabarsa, M.; You, S.G.; Gavlighi, H.A. Structural characteristics, molecular properties and immunostimulatory effects of sulfated polysaccharide from freshwater Myriophyllum spicatum L. Int. J. Biol. Macromol. 2020, 153, 951-961. [CrossRef] [PubMed]

45. Di, T.; Chen, G.; Sun, Y.; Ou, S.; Zeng, X.; Ye, H. Antioxidant and immunostimulating activities in vitro of sulfated polysaccharides isolated from Gracilaria rubra. J. Funct. Foods. 2017, 28, 64-75. [CrossRef] 
46. Leong, Y.K.; Yang, F.-C.; Chang, J.S. Extraction of polysaccharides from edible mushrooms: Emerging technologies and recent advances. Carbohydr. Polym. 2021, 251, 117006. [CrossRef] [PubMed]

47. Luo, X.; Xu, X.; Yu, M.; Yang, Z.; Zheng, L. Characterisation and immunostimulatory activity of an $\alpha$-(1 $\rightarrow 6)-\mathrm{d}$-glucan from the cultured Armillariella tabescens mycelia. Food Chem. 2008, 111, 357-363. [CrossRef] [PubMed]

48. Surayot, U.; Wang, J.; Seesuriyachan, P.; Kuntiya, A.; Tabarsa, M.; Lee, Y.; Kim, J.K.; Park, W.; You, S.G. Exopolysaccharides from lactic acid bacteria: Structural analysis, molecular weight effect on immunomodulation. Int. J. Biol. Macromol. 2014, 68, 233-240. [CrossRef]

49. Bao, H.; Choi, W.S.; You, S.G. Effect of sulfated modification on the molecular characteristics and biological activities of polysaccharides from Hypsizigus marmoreus. Biosci. Biotechnol. Biochem. 2010, 74, 1408-1414. [CrossRef]

50. Chaisuwan, W.; Jantanasakulwong, K.; Wangtueai, S.; Phimolsiripol, Y.; Chaiyaso, T.; Techapun, C.; Phongthai, S.; You, S.G.; Regenstein, J.M.; Seesuriyachan, P. Microbial exopolysaccharides for immune enhancement: Fermentation, modifications and bioactivities. Food Biosci. 2020, 35, 100564. [CrossRef]

51. Hsu, H.Y.; Hua, K.F.; Lin, C.C.; Lin, C.H.; Hsu, J.; Wong, C.H. Extract of Reishi polysaccharides induces cytokine expression via TLR4-modulated protein kinase signaling pathways. J. Immunol. 2004, 173, 5989-5999. [CrossRef] [PubMed]

52. Agarwal, A.; Gupta, U.; Asthana, A.; Jain, N.K. Dextran conjugated dendritic nano constructs as potential vectors for anti-cancer agent. Biomaterials. 2009, 30, 3588-3596. [CrossRef]

53. Zhang, A.; Deng, J.; Yu, S.; Zhang, F.; Linhardt, R.J.; Sun, P. Purification and structural elucidation of a water-soluble polysaccharide from the fruiting bodies of the Grifola frondosa. Int. J. Biol. Macromol. 2018, 115, 221-226. [CrossRef] 